\title{
Lack of antidiabetic effect of a Eugenia jambolana leaf decoction on rat streptozotocin diabetes
}

M.T. Pepato ${ }^{1}$,

V.B.B. Folgado ${ }^{1}$,

I.C. Kettelhut ${ }^{2}$ and

I.L. Brunetti ${ }^{1}$

\author{
1Departamento de Análises Clínicas, Faculdade de Ciências Farmacêuticas de \\ Araraquara, Universidade Estadual Paulista, Araraquara, SP, Brasil \\ ${ }^{2}$ Departamento de Bioquímica, Faculdade de Medicina de Ribeirão Preto, \\ Universidade de São Paulo, Ribeirão Preto, SP, Brasil
}

\section{Correspondence \\ M.T. Pepato \\ Departamento de Análises Clínicas UNESP \\ Caixa Postal 502 \\ 14801-902 Araraquara, SP \\ Brasil \\ Fax: + 55-16-232-0880 \\ E-mail: pepatomt@fcfar.unesp.br \\ V.B.B. Folgado was the recipient of a fellowship from the Programa de Aprimoramento da Fundação do \\ Desenvolvimento Administrativo do Departamento de Análises Clínicas da Faculdade de Ciências \\ Farmacêuticas de Araraquara, SP, Brazil. Publication supported by FAPESP.}

Received M ay 29, 2000 Accepted January 3, 2001

\section{Abstract}

Streptozotocin-diabetic rats were treated for 17 days with a decoction of Eugenia jambolana (Myrtaceae) leaves $(15 \%, \mathrm{w} / \mathrm{v}$ ) as a substitute for water. Body weight, food and fluid intake, urine volume, glycemia, urinary glucose and urea were evaluated every 5 days. The animals were sacrificed by decapitation and blood samples collected for the determination of glycemia, serum cholesterol, HDL-cholesterol, triglycerides and angiotensin-converting enzyme. The weight of adipose and muscle tissues was also determined. There were no statistically significant differences between treated and untreated rats for any of the biochemical or physiological parameters. We conclude that, at least in this experimental model, Eugenia jambolana leaf decoction has no antidiabetic activity.

\section{Introduction}

Plant infusions and decoctions have been used as popular medicines in several underdeveloped and developing countries as an alternative treatment for various conditions, including diabetes mellitus (1). The genus Eugenia (synonym: Syzygium, family: Myrtaceae) has 14 species, including Eugenia uniflora, Eugenia punissifolia, Syzygium jambos (L.) Alst. and Eugenia jambolana Lam. (synonym: Syzygium cumini (L.) skeels, sometimes called Syzygium jambolanum (26)), all of which have been cited as having physiological effects in various species, including man. For example, it has been re-

\section{Key words}

- Antidiabetic plant

- Hyperglycemia

- Diabetic rats

- Eugenia jambolana ported that E. uniflora leaves have diuretic and anti-inflammatory effects (7), antihypertensive effects $(3,8,9)$, antigout effects (7), and hypoglycemic and hypotriglyceridic effects (10). The fruit of this plant has also been reported to have antihypertensive effects (9). The roots of E. punissifolia have been shown to have a hypoglycemic effect in normal and pancreatectomized dogs (4). In Brazil, both E. jambolana and Syzygium jambos are known by the common name Jambolão (2). The leaves of $S$. jambos have been reported to have a hypotensive action (11), and the leaves and flower buds of $E$. jambolana are considered diuretic $(12,13)$. The bark of E. jambolana has shown antidi- 
arrheal effects (14) as well as an inhibitory action against the activity of HIV-1 protease (15), while the seeds of this plant have shown anticonvulsant effects (16).

Eugenia jambolana is frequently used for the treatment of diabetes, and it has been shown that the bark, fruits, seeds or leaves of this plant collected from diverse regions of the world and administered in different pharmaceutical preparations (e.g., tinctures and aqueous extracts) decrease blood glucose levels in diabetic animals (17-22). Also, infusions (simple aqueous extracts prepared with hot water but without boiling) and decoctions (boiled infusions) of E. jambolana have been used in popular medicine for the treatment of diabetes mellitus.

In a southern Brazilian study, most Jambolão users interviewed stated that they either infused or decocted leaves of both $E$. jambolana and $S$. jambos in water at an average concentration of $2.5 \mathrm{~g} / \mathrm{l}$ and drank it in place of water at a mean daily intake of about 1 liter. It was found, however, that $S$. jambos collected in southern Brazil and prepared by these methods did not affect the glycemia of normal individuals (5). Subsequent studies on normal and streptozotocindiabetic rats have also shown that aqueous extracts and decoctions of southern Brazilian E. jambolana have no hypoglycemic effects $(2,23)$.

The majority of the studies cited above in which the presence or absence of hypoglycemic effects was studied were restricted to the evaluation of these effects in animals or nondiabetic humans. Moreover, studies of the effects of chronic treatment with plant extracts are infrequently found in the literature. Because of this, and the contradictory reports appearing in the rare studies which have been carried out with Brazilian Eugenia, the present study with streptozotocin-diabetic rats was carried out to investigate the effects of subchronic administration of $E$. jambolana leaf decoction on several metabolic parameters usually altered in diabetes mellitus.

\section{Material and Methods}

\section{Plant material and decoction preparation}

A tree located in the Medicinal Plants Garden of the School of Pharmacy, Araraquara, SP, Brazil, was identified as Eugenia jambolana by Dr. Gilberto Dolejal Zanetti and authenticated material was deposited in the Herbarium of the Department of Industrial Pharmacy, Federal University of Santa Maria, Santa Maria, RS, Brazil, under accession No. 118. Leaves from this tree were collected in September and October (the end of winter/beginning of spring in southeast Brazil) and used to prepare a decoction according to the recipe used by the local population of Araraquara, i.e., boiling $150 \mathrm{~g}$ of fresh leaves in 1 liter of water for $5 \mathrm{~min}$, allowing the decoction to stand for $30 \mathrm{~min}$ and filtering through simple filter paper. Such procedure resulted in a decoction with a $15 \%$ higher concentration than that produced by the method described by Teixeira et al. (5). A fresh decoction was prepared every 2 or 3 days and kept in dark bottles at $44^{\circ} \mathrm{C}$.

\section{Animals and treatment}

A group of male Wistar rats were adapted to metabolic cages for 2 or 3 days. The animals were then anesthetized with ethyl ether and $40 \mathrm{mg} / \mathrm{kg}$ body weight streptozotocin (STZ) dissolved in $0.01 \mathrm{M}$ citrate buffer, $\mathrm{pH} 4.5$, was injected into the jugular vein. The rats were fasted for 14-16 $\mathrm{h}$ and their mean weight was $158 \pm 2 \mathrm{~g}$. Another group of rats weighing $112 \pm 4 \mathrm{~g}$ were treated in the same way except that they received STZ at the dose of $60 \mathrm{mg} / \mathrm{kg}$ body weight because young rats proved to be more resistant than older ones to the diabetogenic action of STZ (24). All rats were returned to their metabolic cages where they had free access to water and food, being housed under a 12:12$\mathrm{h}$ light/dark cycle at $22-25^{\circ} \mathrm{C}$. The animals were fed a normal laboratory chow diet con- 
taining $(\mathrm{w} / \mathrm{w}) 16 \%$ protein, $66 \%$ carbohydrate and $8 \%$ fat. All experimental protocols were approved by the Ethics Committee.

\section{Decoction administration}

Three days after STZ $(40 \mathrm{mg} / \mathrm{kg}$ body weight) administration, the STZ group had their body weight, plasma glucose (339-387 $\mathrm{mg} / \mathrm{dl}$ ), urinary glucose and food intake measured and these parameters were used to obtain matched pairs of rats with a similar degree of diabetes. One rat in each pair was randomly assigned to a group to be treated with $E$. jambolana decoction (treated group) and the other to an untreated (control) group. Five days after STZ injection, animals in the treated group received E. jambolana decoction in place of water, while the control group received water. Body weight, food and liquid intake, urine volume, plasma and urinary glucose were measured every 5 days at about 9 a.m. During the experiment blood samples for plasma glucose were collected from the tip of the tail. The rats were sacrificed by decapitation 22 days after STZ injection (17-day treatment with E. jambolana decoction) when free running blood was collected for the determination of plasma glucose and serum cholesterol, HDL-cholesterol, triacylglycerol and angiotensin-converting enzyme (ACE). The epididymal fat pad and retroperitoneal adipose tissue overlying the psoas, all pancreatic tissue and the soleus and extensor digitorum longus (EDL) muscles were removed and weighed.

\section{Insulin administration}

Five days after STZ $(60 \mathrm{mg} / \mathrm{kg}$ body weight) injection, body weight, food and liquid intake, urine volume, plasma and urinary glucose and urinary urea were measured. The rats were treated twice a day (9 a.m. and 6 p.m.) with subcutaneous injections of 3 units of NPH insulin (Biohulin N U-100, BioBRÁS, Montes Claros, MG, Bra- zil) for 17 days, after which the same metabolic parameters were again evaluated. These insulin-treated rats served as a further control for the experimental model.

\section{Chemical and statistical analysis}

Urinary glucose was determined by the $o$-toluidine method (25) and urinary urea by a modified diacetyl method (26). ACE was determined by a spectrophotometric assay (27). Plasma glucose and serum cholesterol, HDL-cholesterol and triglycerides were determined with an autoanalyzer (Bayer Technicon RA-100, Tarrytown, NY, USA). Data were analyzed by randomized ANOVA and the paired and unpaired Student $t$-test (GB-STAT program, version 5.0), with the level of significance set at $\mathrm{P}<0.05$.

\section{Results and Discussion}

Table 1 shows the mean values of body weight and the various metabolic parameters for the control group of 10 rats as compared to the treated group of rats which received $E$. jambolana decoction in place of drinking water. It should be remembered that, although the results represent average values, the rats were, in fact, paired as described in Material and Methods.

Analysis of the data in Table 1 shows that none of the metabolic parameters examined was significantly different in the E. jambolana-treated group. Statistically significant differences between treated and control groups were found in water intake on day 5 of treatment and in urine volume on day 10 . However, the statistical significance obtained was due to the relatively low values of fluid intake or urine volume in the control groups at the time periods in question. Indeed, in treated animals these parameters did not differ significantly from the pretreatment values at any of the experimental intervals.

Table 2 presents the results of treatment of STZ-diabetic rats with insulin. The data 
show, as expected, an increase in body weight accompanied by significant $(\mathrm{P}<0.01$ or $\mathrm{P}<0.001$ ) reductions in the values of all the other metabolic parameters, which are usually elevated in diabetes.

The lack of a hypoglycemic effect was also obtained by Teixeira et al. (5) when they administrated E. jambolana aqueous decoction ( $8 \mathrm{~g}$ of leaves per liter) to nondiabetic subjects. These authors also found no effect when they increased the quantity of $E$. jambolana leaves in the decoction (16 and $32 \mathrm{~g}$ of leaves per liter) and administered the decoction as a water substitute to STZ-induced diabetic rats for 14 days or to nondiabetic rats for 14 and 95 days (2). It is interesting also to note that these authors used dried leaves collected in southern Brazil.

It is well known that plant chemical constituents may vary according to humidity, soil and climatic conditions (28), and the lack of effect of E. jambolana reported here does not exclude the possibility of obtaining antidiabetic effects with plants collected at a different time of the year or in a different region and it is also possible that any active compound may be more concentrated in other parts of the plant. Indeed, it has been shown that both seed (18) and bark (17) extracts of E. jambolana can decrease blood glucose levels of diabetic and normal rabbits, while E. jambolana fruit pulp extract reduced blood sugar level within $30 \mathrm{~min}$. The same level of reduction was observed only after $24 \mathrm{~h}$ using seed extracts (21). The treatment of spontaneously diabetic rats for 10 months with $E$. jambolana seed extracts (29) induced cataract regression and reduced glycemia to values close to the normal range $(70-125 \mathrm{mg} /$ dl). The beneficial effects obtained in that study may have been due to the prolonged treatment period and/or the type of diabetic animals used, or might have occurred as a result of a higher concentration of active compounds in the seeds.

More recently, it has been reported that the administration of seed extracts of 2.5-5.0 $\mathrm{g} / \mathrm{kg}$ body weight resulted in a significant reduction of blood glucose, while the administration of seed extract of $7.5 \mathrm{~g} / \mathrm{kg}$ body weight resulted in no significant reduction (19). This suggests that increased concentra-

Table 1 - Metabolic parameters of streptozotocin (STZ)-diabetic rats during oral treatment with a decoction of Eugenia jambolana.

The control group $(C)$ of 10 rats received no decoction, while the treated group $(T)$ of 10 rats received an aqueous E. jambolana leaf decoction in place of drinking water for 17 days. Rats were paired 3 days after STZ injection and treatment was started 5 days after STZ injection. The number in parentheses indicates the days of treatment. Except for body weight and plasma glucose, all values are reported per $100 \mathrm{~g}$ body weight. Data are reported as means \pm SEM. $* P<0.05$ compared to control (ANOVA and unpaired Student t-test).

\begin{tabular}{|c|c|c|c|c|c|c|c|c|}
\hline \multirow[t]{3}{*}{ Metabolic parameters } & \multicolumn{8}{|c|}{ Days after streptozotocin injection } \\
\hline & \multicolumn{2}{|c|}{3} & \multicolumn{2}{|c|}{$10(5)$} & \multicolumn{2}{|c|}{$15(10)$} & \multicolumn{2}{|c|}{$22(17)$} \\
\hline & $\mathrm{C}$ & $\mathrm{T}$ & $\mathrm{C}$ & $\mathrm{T}$ & $\mathrm{C}$ & $\mathrm{T}$ & $\mathrm{C}$ & $\mathrm{T}$ \\
\hline Body weight (g) & $159 \pm 5$ & $156 \pm 3$ & $198 \pm 5$ & $186 \pm 4$ & $234 \pm 5$ & $234 \pm 5$ & $264 \pm 4$ & $250 \pm 14$ \\
\hline Fluid intake $(\mathrm{ml} / 24 \mathrm{~h})$ & $55 \pm 3$ & $69 \pm 10$ & $50 \pm 4$ & $70 \pm 6^{*}$ & $43 \pm 4$ & $52 \pm 5$ & $49 \pm 6$ & $64 \pm 4$ \\
\hline Food intake (g/24 h) & $17.0 \pm 0.7$ & $18.0 \pm 0.7$ & $17.9 \pm 0.9$ & $18.6 \pm 1.3$ & $15.6 \pm 1.2$ & $19.3 \pm 1.3$ & $14.6 \pm 1.4$ & $15.3 \pm 1.4$ \\
\hline Urine volume (ml/24 h) & $29 \pm 4$ & $36 \pm 5$ & $30 \pm 2$ & $37 \pm 6$ & $20 \pm 2$ & $32 \pm 5^{*}$ & $24 \pm 4$ & $31 \pm 6$ \\
\hline Urinary glucose ( $g / 24 \mathrm{~h})$ & $2.1 \pm 0.3$ & $2.7 \pm 0.4$ & $2.0 \pm 0.3$ & $2.5 \pm 0.4$ & $1.2 \pm 0.2$ & $2.2 \pm 0.4$ & $1.6 \pm 0.4$ & $2.2 \pm 0.4$ \\
\hline Urinary urea (mg/24 h) & $573 \pm 52$ & $636 \pm 66$ & $601 \pm 54$ & $661 \pm 88$ & $521 \pm 58$ & $633 \pm 90$ & $518 \pm 135$ & $653 \pm 171$ \\
\hline Plasma glucose (mg/dl) & $357 \pm 39$ & $370 \pm 31$ & $344 \pm 21$ & $407 \pm 50$ & $377 \pm 34$ & $388 \pm 42$ & $283 \pm 68$ & $326 \pm 54$ \\
\hline
\end{tabular}


tions of active compounds in plant extracts are not always beneficial, and can even promote adverse biological effects.

Table 3 shows that there was no alteration in either serum triglyceride level (also in serum cholesterol and HDL-cholesterol levels) or adipose tissue weight in STZ-diabetic rats receiving the E. jambolana decoction, indicating that this treatment did not improve lipid metabolism. In a similar study of STZ-diabetic rats treated for 19 days with Myrcia uniflora (a plant found in the Brazilian Amazon called Pedra-hume-caá in Portuguese) there was no increase in body weight or the weight of epididymal and retroperitoneal adipose tissue but there were significant reductions in hyperglycemia, polyphagia, urine volume and urinary excretion of glucose and urea (30). The lack of effects by $E$. jambolana on serum triglyceride levels (Table 3 ) contrasts with some in vitro studies using $70 \%$ ethanol extracts of Eugenia uniflora leaves, which have shown that two fractions have an inhibitory effect on pancreatic lipase activity resulting in improvement of hypertriglyceridemia in mice (10).

It also appears that $E$. jambolana treatment did not result in better protein metabolism in STZ-diabetic rats because urinary urea was similar in the control and treated groups (Table 1), which is in agreement with the fact that there was no alteration in soleus or EDL muscle weight (Table 3).

The activity of ACE, an enzyme involved in vascular changes in diabetic kidneys $(31,32)$, is increased in diabetic animals $(33,34)$, but it seems that the E. jambolana decoction has no protective effect on blood vessels since ACE levels were similar in both the treated and control groups (Table 3).

In this report, evidence is presented that the subchronic oral administration of a fresh E. jambolana leaf decoction to STZ-diabetic rats is not useful for the treatment of diabetes because there were no significant positive changes in the biochemical or physiological parameters investigated. It is possible that these negative results may have been due to factors such as the geographical location of the specific E. jambolana tree used, the season in which the leaves were collected, the fact that only leaves were used (other parts of the tree could have different effects), the concentration of the decoctions and the type of diabetes induced. It is still possible, however, that E. jambolana leaf extracts might be useful in the treatment of human type 2 diabetes, because the STZ-diabetes model used here is more correlated to type 1 diabetes.

Table 2 - Metabolic parameters of streptozotocin (STZ)-diabetic rats before and after 17 days of treatment with insulin.

Treatment was started 5 days after STZ injection. Except for body weight and plasma glucose, all values are reported per $100 \mathrm{~g}$ body weight. $* \mathrm{P}<0.01$, **P $<0.001$ compared to the group before insulin treatment (paired Student t-test).

\begin{tabular}{lcc}
\hline Metabolic parameters & Before insulin treatment & After insulin treatment \\
\hline Body weight $(\mathrm{g})$ & $130 \pm 4$ & $231 \pm 7^{* *}$ \\
Fluid intake $(\mathrm{ml} / 24 \mathrm{~h})$ & $72 \pm 4$ & $33 \pm 2^{* *}$ \\
Food intake $(\mathrm{g} / 24 \mathrm{~h})$ & $20.9 \pm 1.7$ & $12.9 \pm 2.4^{* *}$ \\
Urine volume $(\mathrm{ml} / 24 \mathrm{~h})$ & $44 \pm 4$ & $19 \pm 2^{* *}$ \\
Urinary glucose $(\mathrm{g} / 24 \mathrm{~h})$ & $3.5 \pm 0.3$ & $0.9 \pm 0.2^{* *}$ \\
Urinary urea $(\mathrm{mg} / 24 \mathrm{~h})$ & $787 \pm 62$ & $524 \pm 63^{*}$ \\
Plasma glucose $(\mathrm{mg} / \mathrm{dl})$ & $509 \pm 18$ & $74 \pm 9^{*}$
\end{tabular}

Table 3 - Serum parameters and tissue weight of streptozotocin-diabetic rats after oral treatment with a decoction of Eugenia jambolana for 17 days.

The control group of 10 rats received no decoction, while the treated group of 10 rats received an oral aqueous $\mathrm{E}$. jambolana leaf decoction for 17 days. ${ }^{1} \mathrm{mg} / 100 \mathrm{~g}$ body weight. $\mathrm{ACE}=$ Angiotensin-converting enzyme, $\mathrm{EDL}=$ extensor digitorum longus .

\begin{tabular}{lcc}
\hline Serum parameters and tissue weight & Control group & Treated group \\
\hline Cholesterol (mg/dl) & $52 \pm 3$ & $56 \pm 1$ \\
HDL-cholesterol (mg/dl) & $42.2 \pm 2.4$ & $43.3 \pm 0.9$ \\
Triglycerides (mg/dl) $^{\prime}$ & $110 \pm 12$ & $90 \pm 15$ \\
ACE (IU) & $1610 \pm 315$ & $1392 \pm 157$ \\
Epididymal fat $^{1}$ & $398 \pm 64$ & $454 \pm 51$ \\
Retroperitoneal fat $^{1}$ & $223 \pm 35$ & $153 \pm 56$ \\
Soleus muscle $^{1}$ & $50.0 \pm 1.2$ & $51.0 \pm 1.1$ \\
${\text { EDL } \text { muscle }^{1}}_{\text {Pancreas }^{1}}$ & $45.2 \pm 0.8$ & $45.8 \pm 1.0$
\end{tabular}




\section{Acknowledgments}

The authors thank Dr. Renato $\mathrm{H}$. Migliorini, Dr. Sandro Roberto Valentini and Dr. Robert W.S.P. Thomas for a critical reading of the manuscript, and Dr. Gilberto
Dolejal Zanetti, Herbarium of the Industrial Pharmacy Department, Federal University of Santa Maria, Santa Maria, RS, Brazil, for the identification and authentication of $E$. jambolana.

\section{References}

1. Elisabetsky E (1987). Pesquisas em plantas medicinais. Ciência e Cultura, 39: 697702.

2. Teixeira CC, Pinto LP, Kessler FHP, Knijnik L, Pinto CP, Gastaldo GJ \& Fuchs FD (1997). The effect of Syzygium cumini (L.) skeels on post-prandial blood glucose levels in non-diabetic rats and rats with streptozotocin-induced diabetes mellitus. J ournal of Ethnopharmacology, 56: 209-213.

3. Consolini AE, Baldini OAN \& Amat AG (1999). Pharmacological basis for the empirical use of Eugenia uniflora L. (Myrtaceae) as antihypertensive. J ournal of Ethnopharmacology, 66: 33-39.

4. Arruda LFMR, Freitas ACS, Granjeiro OP, Aquino EG \& Martins MF (1984). Estudo dos efeitos farmacológicos induzidos pelo extrato aquoso de raizes de Eugenia punissifolia (HBK) DC. VIII Symposium on Brazilian Medicinal Plants, Manaus, AM, Brazil, May 11-16.

5. Teixeira CC, Fuchs FD, Blotta RM, Knijnik J, Delgado IC, Netto MS, Ferreira E, Costa AP, Mussnich DG, Ranquetat GG \& Gastaldo G (1990). Effect of tea prepared from leaves of Syzygium jambos on glucose tolerance in nondiabetic subjects. Diabetes Care, 13: 907-908.

6. Index Kewensis (1960). Plantarum phanerogamarum nomina et synonyma omnium generum et specerum a Linnaeo usque ad annum 1895 complectens. Clarendon Press, Oxford, 2: 1027 (Abstract).

7. Schmeda-Hirschmann G, Theoduloz C, Franco L, Ferro E \& de Arias AR (1987). Preliminary pharmacological studies on Eugenia uniflora leaves: xanthine oxidase inhibitory activity. J ournal of Ethnopharmacology, 21: 183-186.

8. Schmeda-Hirschmann G (1988). Ethnobotanical observations on Paraguayan Myrtaceae. J ournal of Ethnopharmacology, 22: 73-79.

9. Amat $A G \&$ Yajía ME (1991). Medicinal plants and ethnopharmacology in the province of Misiones (Argentina). Acta Farmacéutica Bonaerense, 10: 153-159.

10. Arai I, Amagaya S, Komatsu Y, Okada M,
Hayashi T, Kasai M, Arisawa M \& Momose $Y$ (1999). Improving effects of the extracts from Eugenia uniflora on hyperglycemia and hypertriglyceridemia in mice. J ournal of Ethnopharmacology, 68: 307-314.

11. Romero MJ (1995). Acción cardiovascular de extractos acuosos de hojas de Syzygium jambos (L.) Alston. Revista Costarricence de Ciências Médicas, 16: 17-25.

12. Silva Neto CR, Lopes RA \& Pozetti GL (1986). Efeitos do extrato de folhas secas de jambolão (Syzygium jambolanum) sobre a excreção renal de água, sódio e potássio em ratos. Resultados preliminares. Revista da Faculdade de Odontologia de Ribeirão Preto, 23: 213-215.

13. Silva Neto CR, Lopes RA \& Pozetti GL (1989). Utilização de extrato de botão floral de jambolão (Syzygium jambolanum) na excreção renal de água e eletrólitos em ratos. Pesquisa Homeopatica, 4: 1521.

14. Mukherjee PK, Saha K, Murugesan T, Mandal SC, Pal M \& Saha BP (1997). Screening of anti-diarrhoeal profile of some plant extracts of a specific region of West Bengal, India. J ournal of Ethnopharmacology, 60: 85-89.

15. Kusumoto IT, Nakabayashi T, Kida $H$, Miyashiro $H$, Hattori $M$, Namba $T \&$ Shimotohno K (1995). Screening of various plant extracts used in ayuvedic medicine for inhibitory effects on human immunodeficiency virus type 1 (HIV-1) protease. Phytotherapy Research, 9: 180184.

16. De Lima TCM, Klueger PA, Pereira PA, Macedo-Neto WP, Morato GS \& Farias MR (1998). Behavioural effects of crude and semi-purified extracts of Syzygium cumini Linn. skeels. Phytotherapy Research, 12: 488-493.

17. Ratsimamanga $A R$, Loiseau $A$, Ratsimamanga-Unverg $S \&$ Bibal-Prot $P$ (1973). Nouvelle contribution à l'étude de l'action d'un principe hypoglycémiant mis en évidence dans d'écorce jeune de Eugenia jambolana (Myrtacées) sur l'hyper- glicémie provoquée du lapin normal et pursuite de sa purification. Comptes Rendus Hebdomadaires des Séances de I'Académie des Sciences. Serie D, Sciences Naturelles, 277: 2219-2222.

18. Kedar P \& Chakrabarti CH (1983). Effects of jambolan seed treatment on blood sugar, lipids and urea in streptozotocin induced diabetes in rabbits. Indian J ournal of Physiology and Pharmacology, 27: 135-140.

19. Prince PS, Menon VP \& Pari L (1998). Hypoglycaemic activity of Syzygium cumini seeds: effect on lipid peroxidation in alloxan diabetic rats. J ournal of Ethnopharmacology, 61: 1-7.

20. Sigogneau-J agodzinski $M$, Bibal-Prot $P$, Chanez M, Boiteau P \& Rakoto A (1967). Contribution à l'étude de l'activité hypoglycémiante et antidiabétique d'un principe extrait du Totra de Madagascar (Eugenia jambolana Lamarck). Comptes Rendus de l'Académie des Sciences, 264: 1119-1123.

21. Achrekar S, Kaklij GS, Pote MS \& Kelkar SM (1991). Hypoglycemic activity of Eugenia jambolana and Ficus bengalensis: mechanism of action. In Vivo, 5: 143-147.

22. Petenusci SO, Lopes RA, Sala MA, Pozetti GL, Bernardi AC \& Cabrera A (1986). Estudio de la acion hipoglicemiante de las hojas de yambo (Syzygium jambolanum) en ratas com diabetes aloxanica. Ars Pharmaceutica, XXVII: 193-196.

23. Teixeira CC, Rava CA, Da Silva PM, Melchior R, Argenta R, Anselmi $F$, Almeida CRC \& Fuchs FD (2000). Absence of antihyperglycemic effect of jambolan in experimental and clinical models. J ournal of Ethnopharmacology, 71: 343-347.

24. Pepato MT, Migliorini RH, Goldberg AL \& Kettelhut IC (1996). Role of different proteolytic pathways in degradation of muscle protein from streptozotocin-diabetic rats. American J ournal of Physiology, 271: E340-E347.

25. Duboswski KM (1962). An o-toluidine method for body fluid glucose determination. Clinical Chemistry, 9: 215-235. 
26. Wibenga DR, Di Giorgio J E \& Pileggi VJ (1971). Manual and automated methods for urea nitrogen measurement in whole serum. Clinical Chemistry, 17: 891-895.

27. Groff J L, Harp J B \& DiGirolamo M (1993). Simplified enzymatic assay of angiotensin-converting enzyme in serum. Clinical Chemistry, 39: 400-404.

28. Evans WC (1996). Commerce and production: principles related to the commercial production, quality and standardization of natural products. In: Trease GE \& Evans WC (Editors), Pharmacognosy. 14th edn. Saunders, London.

29. Chivan-Nia MMP \& Ratsimamanga AR (1972). Régression de la cataracte et de l' hyperglycémie chez le rat des sables (Psammomys obesus) diabétique ayant reçu un extrait de Eugenia jambolana (Lamarck). Comptes Rendus Hebdomadaires des Séances de l'Académie des Sciences. Serie D, Sciences Naturelles, 274: 254-257.

30. Pepato MT, Oliveira J R, Kettelhut IC \& Migliorini RH (1993). Assessment of the antidiabetic activity of Myrcia uniflora extracts in streptozotocin-diabetic rats. Diabetes Research, 22: 49-57.

31. Vranes D, Dilley RJ \& Cooper ME (1995). Vascular changes in the diabetic kidney: effects of ACE inhibition. J ournal of Diabetes and its Complications, 9: 296-300.

32. Valentovic MA, Elliott $\mathrm{CM} \&$ Ball JG (1987). The effect of streptozotocin-induced diabetes and insulin treatment on angiotensin converting enzyme activity.
Research Communications in Chemical Pathology and Pharmacology, 58: 27-39.

33. Erman A, Chen-gal B, David I, Giler S, Boner G \& Van Dijk DJ (1998). Insulin treatment reduces the increased serum and lung angiotensin converting enzyme activity in streptozotocin-induced diabetic rats. Scandinavian J ournal of Clinical and Laboratory Investigation, 58: 81-87.

34. Gilbert RE, Cox A, Wu II, Allen TJ , Hulthen UI, J erums G \& Cooper ME (1998). Expression of transforming growth factorbeta and type IV collagen in the renal tubulointerstitium in experimental diabetes: effects of ACE inhibition. Diabetes, 47: 414-422. 